\section{KRASTEV*, TS. DOBROVOLSKA}

Institute of Physical Chemistry, Bulgarian Academy of Sciences, Sofia, Bulgaria
Scientific paper

ISSN 0351-9465, E-ISSN 2466-2585

UDC:620.197.5:669.018

doi:10.5937/ZasMat1601156K

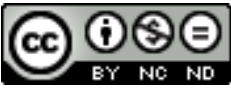

Zastita Materijala 57 (1)

$156-165(2016)$

\title{
New examples of electrodeposited alloy systems with pattern formation
}

\begin{abstract}
The experience in the pattern formation during electrodeposition of alloys is summarized. The possibility of formation of spatio-temporal structures due to the spontaneous co-deposition of different phases and their self-organization in ordered structures is demonstrated in some new not investigated in this aspect alloy systems, like Cu-Sb, Ag-Sn, Pd-In and Au-In.

Key words: Electrodeposition of alloys, pattern formation, SEM, XRD, ALSV.
\end{abstract}

\section{INTRODUCTION}

E. Raub and A.Schall [1] observed 1938 for the first time formation of spatio-temporal structures on the surface of the cathode during electrodeposition of Ag-In alloy. They reported about the observation of "crystallization spirals" formed by indium-richer phases on the surface of the alloy coating. Later similar structures were observed during electrodeposition of many other alloy systems, at the beginning starting with some other silver alloys, like AgSb [2,3], AgBi [4], AgIn [5], AgCd [6], AgSn [7], deposited from alkaline cyanide electrolytes. Later the phenomenon was discovered in some other alloy systems electrodeposited from acid, non-cyanide electrolytes (InCo [8], CuSb [9], SbCo [10]). Different electrolytes for the deposition of the mentioned alloys were proposed, the electrode processes were investigated in the proposed electrolytes, the arising instabilities under potentiostatic or galvanostatic conditions were described, the composition, as well the phase composition and the structure of the deposits was determined depending on the electrolysis conditions and the pattern formation in the investigated systems was described. The properties of the obtained alloy

${ }^{*}$ Corresponding author: I. Krastev

E-mail: krastev@ipc.bas.bg

Paper received: 28. 11. 2015.

Paper accepted: 21. 01. 2016.

Paper is available on the website: www.idk.org.rs/casopis coatings as well as the properties of cyclic modulated alloy coatings on their basis were thoroughly investigated. The main area of the gathered new knowledge during investigations of these systems could be summarized as follows:

1. Instabilities appear in some electrodeposition systems leading to spontaneous oscillations of current (AgSb [11] ) or potential (AgCd [12], AgSn [13]) or both (AgCd [12]) depending on the deposition mode. Regions with negative resistance can be observed on the polarization curve (AgSb [14]).

2. At high concentrations of the alloying element heterogeneous multiphase coatings are deposited. Depending on the concentration of the alloying element, they consist of the basic metal, solid solution of the alloying element in the basic metal, phases with different ratio of both elements and intermetallic compounds, and the pure alloying metal. At low current densities in galvanostatic deposition mode mainly the positive element is deposited and monophasic coatings are obtained. Increasing the current density in the regular systems according to Brenner [15] a solid solution is formed. After saturation of the lattice of the more positive element with atoms of the alloying metal (often after reaching the limited current density for the more positive element), the excess amount of the latter forms a new richer in this element phase and heterogeneous coatings are obtained. Mostly some similarity of the lattices of these different phases is observed enabling their easier transition in each other AgSb [16,17] AgCd [18]. 
3. At certain conditions (non-agitated electrolytes) the heterogeneity in the coatings surface becomes ordered - self-organization phenomena are observed. The upward moving of the electrolyte due to the natural convection initiated by the Archimedes power after depletion of the heavy metal ions in the cathodic layer due to their deposition is one of the main factors contributing to the development of the patterned structures. It was shown, that the appearing electrochemical instability is flow induced (AgSb [19]). In other cases the instability is originated by the formation and destruction of passive films on the electrode ( $\mathrm{AgCd}[12])$. The hydrodynamic motion of the electrolyte is a necessary element for the motion and spreading of the structures on the electrode surface. It favors the preferential deposition of the more positive element. At very intensive motion of the electrolyte (strong agitation or plating in a jet-cell) the spatio-temporal structures are formed at correspondingly higher current densities, leading to a similar percentage and phase composition of the coatings (InCo [8]).

4. Different forms of spatio-temporal organized structures are observed - spots, waves, targets and spirals. They differ in their size, periods (more than 10 times larger period in Agln [20,21], than in the AgSb [2,22] spirals), spreading velocity (faster in AgSb [23], than in AgIn[21], $\mathrm{AgCd}$ [12], or $\mathrm{AgBi}$ [4] structures) and phase composition. The main difference between the different phases in each system allowing their recognition and observation is the difference in their optical properties (dark and light areas).

5. The phase composition of the obtained structured coatings is mostly very complicated. The $x$-ray investigations show the presence of several phases in the coatings. Due to the great difference in the spreading velocity of the patterns and the increase in the thickness of the coating in the same time, the upward moving of dark and light waves on the electrode surface forms a multilayered coating with a very small thickness of the sublayer, which is smaller than the penetration depth of the electron beam in the electron microscope. That means that with the normal techniques the phase composition of the different areas of the observed spatiotemporal structures cannot be established. A possibility for determination of the phase composition of the different elements of the structures offers the electrochemistry, and special the anodic linear sweep voltammetry (ALSV) in combination with $\mathrm{X}$-ray and microscopic observations using the principle, that each phase in the coating has its own dissolution potential in an appropriate electrolyte. Using these methods it was possible to show, that the structures are formed by the phases $\mathrm{Cd}$ and $\mathrm{Cd}_{3} \mathrm{Ag}$ ( $\left.\mathrm{AgCd}[18]\right), \mathrm{Ag}$ and $\mathrm{Ag}_{3} \ln (\mathrm{Ag} \ln [24])$, $\mathrm{Co}$ and $\mathrm{Co}_{3} \ln$ (InCo [8]) etc.

6. In many cases the spatio-temporal structures are formed on the basis of the richer in the more positive element phases of the alloy system (AgSb [16], Agln [25], AgSn [7]), in other cases - on the basis of the richer in the more negative element phase components (AgCd [18], $\mathrm{AgBi}[4])$, as well as in systems where the deposition potentials of both elements are very close to each other (InCo [8]).

7. The heterogeneous micro- and nano-scale structured coatings have properties which combines the properties of the different phases presented in the coating. The electric parameter of the coatings are influenced (Ag Sb [26], Agln [27], AgSn [13], AgBi [4], AgCd [27]), some new effects at low temperatures are registered (AgSb [28]), the hardness and the tribological properties (abrasion resistance, plug-in forces) of the alloys compared to the pure metals are changed (AgSb [26], Agln [27] , AgSn [13], AgBi[4]), giant magnetoresistance (AgCo [29]) and magnetic micro patterning is observed (InCo [30]). The properties of the cyclic modulated alloy multilayers are investigated depending on the electrolysis conditions and the number and composition of the separate sublayers (AgSb [31], AgBi [32]), as well as the spontaneous formation of multilayers without application of pulsating current is observed (AgSn [13]).

The experience and the knowledge about the appearance of the self-organization phenomena in a lot of previously investigated systems allow the assumption, that similar pattern formation could be registered also during electrodeposition of many other alloy systems.

The aim of this paper is to introduce some new examples of electrodeposited alloy systems with pattern formation investigated recently. The investigations were performed as continuation of previous research on the electrodeposition of the alloys CuSb [9] and Ag-Sn[7], and as a new investigations on the deposition of indium alloys with the noble metals $\mathrm{Pd}$ and $\mathrm{Au}$.

\section{EXPERIMENTAL}

The compositions of the electrolytes for the deposition of the alloy coatings are presented in Table1. Distilled water and pro analisi grade reagents were used for the preparation of the electrolytes. The CV experiments were performed in a $100 \mathrm{~cm}^{3}$ tri-electrode glass cell at room temperature. The working electrode (area $1 \mathrm{~cm}^{2}$ ) and the two counter electrodes were made from platinum. In the electrolyte for deposition of $\mathrm{Au}$-In alloy the working electrode was gold. $\mathrm{An} \mathrm{Ag} / \mathrm{AgCl}$ reference electrode $\left(\mathrm{E}_{\mathrm{Ag} / \mathrm{AgCl}}=0.197 \mathrm{~V}\right.$ vs. $\left.\mathrm{NHE}\right)$ was used. 
Table 1 - Composition of the electrolytes

\begin{tabular}{|c|c|c|c|c|}
\hline \multirow{2}{*}{ Components } & \multicolumn{4}{|c|}{ Concentration, $\mathrm{g} \mathrm{dm}^{-3}$} \\
\hline & $\mathrm{Cu}-\mathrm{Sb}$ & $\mathrm{Ag}-\mathrm{Sn}$ & Pd-In & Au-In \\
\hline $\mathrm{Sb}$ as $\mathrm{K}(\mathrm{SbO}) \mathrm{C}_{4} \mathrm{H}_{4} \mathrm{O}_{6.1} 1 / 2 \mathrm{H}_{2} \mathrm{O}$ & 27 & & & \\
\hline $\mathrm{Cu}$ as $\mathrm{CuSO}_{4} \cdot 5 \mathrm{H}_{2} \mathrm{O}$ & 2.4 & & & \\
\hline Methanesulfonic acid, $\mathrm{ml} \mathrm{dm}^{-3}$ & 20 & & & \\
\hline $\mathrm{D}(-)-\mathrm{C}_{4} \mathrm{H}_{6} \mathrm{O}_{6}$ & 96 & & & \\
\hline $\mathrm{Au}$ as $\mathrm{KAu}(\mathrm{CN})_{2}$ & & & & 1 \\
\hline In as $\left.\operatorname{lnCl}\right|_{3 / \text { Alfa Aesar/ }}$ & & & 9 & 6 \\
\hline$\left(\mathrm{NH}_{4}\right)_{2} \mathrm{SO}_{4 / \mathrm{Merck} /}$ & & & 10 & 40 \\
\hline Glycine & & & & 40 \\
\hline $\mathrm{Pd}$ as Palluna 460 /Umicore ${ }^{*},\left(\mathrm{ml} \mathrm{dm}^{-3}\right)$ & & & 3 & \\
\hline $\mathrm{C}_{6} \mathrm{H}_{5} \mathrm{Na}_{3} \mathrm{O}_{7} \cdot 5 \mathrm{H}_{2} \mathrm{O}_{\text {/Merck }}$ & & & 10 & \\
\hline $\mathrm{NH}_{4} \mathrm{Cl}_{\text {Merck }}$ & & & 10 & \\
\hline $\mathrm{Sn}$ as $\mathrm{Sn}_{2} \mathrm{P}_{2} \mathrm{O}_{7}$ /umicore/ & & 30 & & \\
\hline $\mathrm{Ag}$ as $\mathrm{KAg}(\mathrm{CN})_{2 / \text { Umicore/ }}$ & & 16 & & \\
\hline $\mathrm{C}_{4} \mathrm{H}_{4} \mathrm{O}_{6} \mathrm{KNa} 4 \mathrm{H}_{2} \mathrm{O}$ & & 60 & & \\
\hline $\mathrm{K}_{4} \mathrm{P}_{2} \mathrm{O}_{7 / \text { Umicore/ }}$ & & 280 & & \\
\hline $\mathrm{KSCN}_{\text {Merck }}$ & & 60 & & \\
\hline $\mathrm{pH}$ & 1.1 & 8.0 & 9.3 & 3.5 \\
\hline
\end{tabular}

The experiments were performed by means of a computerized potentiostat/galvanostat Princeton Applied Research Model 273 using the software PowerSuite.

The alloy coatings with thickness between 3 and $25 \mu \mathrm{m}$ were deposited onto brass substrates with an area of $2 \times 1 \mathrm{~cm}$ in the glass cell. The preliminary preparation of the cathodes includes a standard procedure of electrochemical degreasing followed by pickling in a $20 \%$ solution of sulphuric acid. Two Pt (Ti) counter electrodes (about $4 \mathrm{~cm}^{2}$ each) were used.

The percentage of the alloys (as well as their thickness) in the coatings depending on the electrolysis conditions, was determined by $\mathrm{X}$-ray fluorescence analysis (Fischerscope X-RAY XDAL) in 3 points (in the bottom, middle and top of the sample, respectively). The distribution of the alloying elements on the surface of the coatings was examined by energy dispersive X-ray analysis (EDX).

The surface morphology of the coatings was investigated by scanning electron microscopy (SEM) - JEOL JSM 6390. The phase composition was characterized by X-ray diffraction (XRD) using a PANalytical Empyrean device equipped with a multichannel detector (Pixel 3D) using Cu-Ka (45 $\mathrm{kV}, 40 \mathrm{~mA}$ ) irradiation in the $2 \theta$ range $20-115^{\circ}$, with a scan step of $0.01 \circ$ for $20 \mathrm{~s}$.

\section{RESULTS}

\subsection{Electrodeposition of Cu-Sb alloys}

The high corrosion resistance, high metallic lustre and wide range of applications of $\mathrm{Sb}$ and its alloys make their electrodeposition of practical importance [33]. For example the addition of Sb to $\mathrm{Cu}$ improves the physico-mechanical properties of $\mathrm{Cu}$ coatings, as well as their corrosion resistance [34]. Up to $5 \% \mathrm{Sb}$ in the coatings give them decorative appearance [35]. In the literature the data about $\mathrm{Cu}-\mathrm{Sb}$ electrodeposition are scarce. Pyrophosphate [35], ammoniacal [36], cyanide [37], tartrate-cyanide $[34,37,38]$, carbonate-tartrate containing $\mathrm{HC} 1$ [39], sulfate-tartrate [40] and polyphosphate [41] baths were proposed for $\mathrm{Cu}-\mathrm{Sb}$ deposition. $\mathrm{Cu}-\mathrm{Sb}$ alloys with low antimony content are deposited from most of these electrolytes. Some of the electrolytes suffer from shortcomings such as frequent corrections of $\mathrm{Sb}$ concentration, toxicity etc. Recently, some investigations on the deposition of the alloy from methanesulphonatetartrate baths were reported [9]. It was shown that from this type of electrolyte compact coatings with up to 50 wt. \% antimony can be obtained and the co-deposition of high antimony contents results in the formation of heterogeneous multiphase coatings. Based on the same type of electrolyte the goal of the present investigation was, by changing 
drastically the metal content in the electrolyte to find out the conditions of electrolysis where the self-organization of the different phases is expressed in the form of higher-ordered structures - waves, spirals and targets. The task was to establish the electrolysis conditions for the preparation of structured and unstressed purplepink coatings on the alloy $\mathrm{Cu}-\mathrm{Sb}$, including their phase characterization.

Copper is in the proposed electrolyte the more positive element compared with antimony. In order to apply current densities in a large interval enabling the continuous increase in the amount of co-deposited antimony, the concentrations of copper in the electrolyte was increased about twice and the concentration of antimony - reduced about 8 times, compared with our previous studies. The result of this optimization is presented on Figure 1, showing the antimony percent in the coating depending on the current density. Coatings with up to $80 \%$ antimony can be obtained from this electrolyte. At low current densities the coatings are pink, copper-like and at the 0.3-0.4 $\mathrm{A} \mathrm{dm}^{-2}$ some optical heterogeneity like a darker spots and dots appear onto the cathode surface.

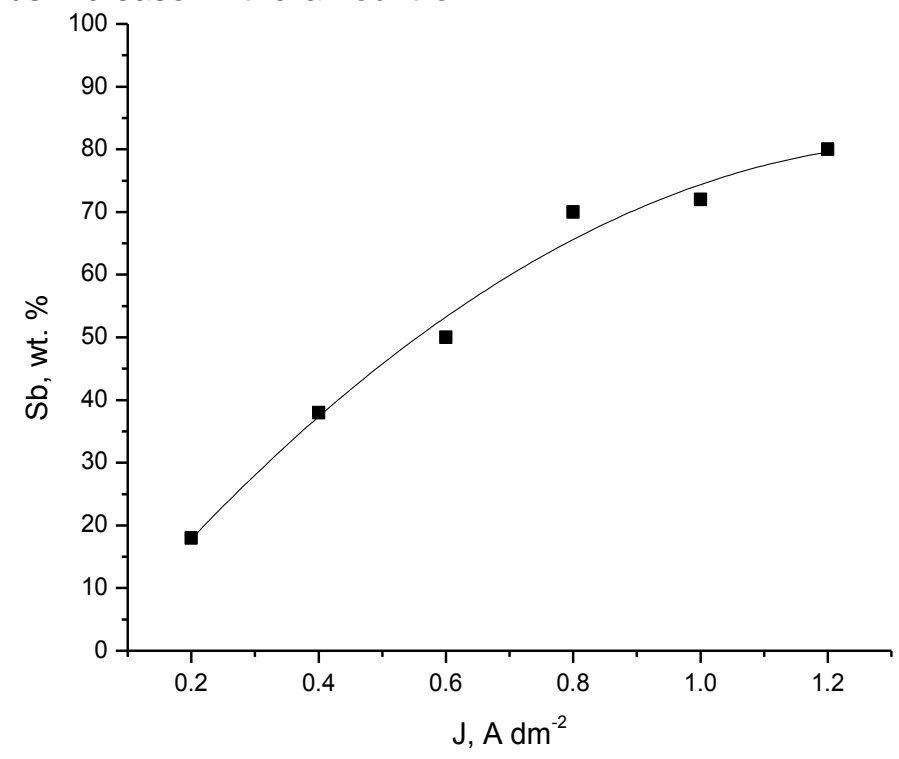

Figure 1 - Antimony content in the alloy coatings depending on the current density

After $0.5 \mathrm{~A} \mathrm{dm}^{-2}$ the coatings are lilac and at the highest current densities (after $1.3 \mathrm{~A} \mathrm{dm}^{-2}$ ) they are shiny and stressed, with a lot of cracks. The deposition rate increases with increasing the current density up to $0.7 \mu \mathrm{m} \mathrm{min}^{-1}$, which is a relative high deposition rate at similar electrolysis conditions compared to the other alloy systems [17].

Figure 2 presents the $x$-ray diffractogram of a coating deposited at $0.4 \mathrm{~A} \mathrm{dm}^{-2}$, where the reflexes of the substrate $\left(\mathrm{Cu}_{2.6} \mathrm{Zn}_{1.4}\right)$, of pure antimony as well as the phases $\mathrm{Cu}_{2} \mathrm{Sb}_{1}$ and $\mathrm{Cu}_{11} \mathrm{Sb}_{3}$ are registered. The phase heterogeneity of the coatings is visible also in on their surface. Most probably, the structures are formed by the phases $\mathrm{Cu}_{2} \mathrm{Sb}$ and $\mathrm{Cu}_{11} \mathrm{Sb}_{3}$, but the exact evidence should be based on combined x-ray, microscopic and electrochemical (ALSV) measurements.

Figure 3 shows the space distribution of the different phases on surface of the coating, which diffractogram is shown on Figure 2. The initial stages of the formation of ordered structures is obvious. The future optimization of the system should result in strongly ordered periodic structures with periods corresponding to the deposition conditions.

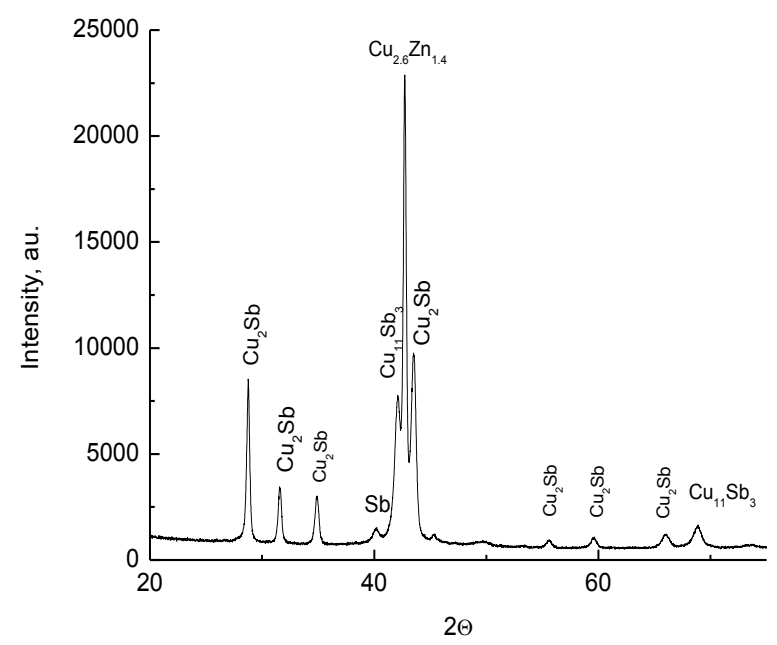

Figure 2 - X-Ray diffractogram of the sample, deposited at $0.4 \mathrm{~A} . \mathrm{dm}^{-2}$; about 40 wt. \% Sb; thickness of the coating $24 \mu \mathrm{m}$. 


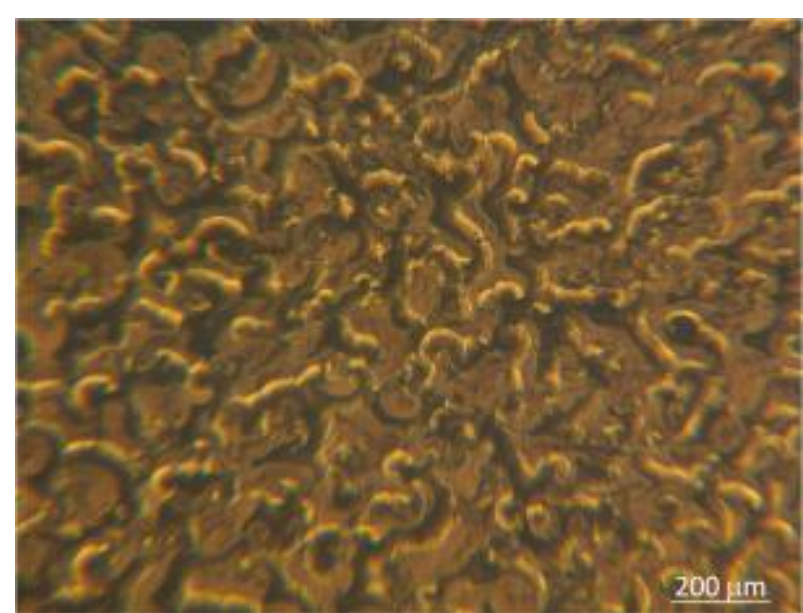

Figure 3 - Spatio-temporal structures on the surface of the $\mathrm{Cu}$-Sb coating with a diffractogram presented in Figure 2.

\subsection{Electrodeposition of Ag-Sn alloys}

A detailed literature survey on the electrodeposition of $\mathrm{Ag}-\mathrm{Sn}$ alloys is presented elsewhere [7]. Silver-tin alloy is a very important material for solders, especially after the strict regulations of EU on the use of lead. Despite the intensive efforts of the scientific community stable electrolytes for deposition of this alloy are still not formulated .The main reason is the oxidation of the two valent tin ions to a tetravalent valent ones, wherein the silver ion is reduced immediately in the solution One of the few electrolyte options for the deposition of silver-tin alloys is the cyanidepyrophosphate electrolyte [7].

Our previous results demonstrated the possibility to observe spatio-temporal structures on the surface of the alloy deposit [7], as well as the possibility to obtain periodical multilayered alloy coatings without applying pulse plating methods [13]. The very well formed multilayers appeared as a result of the electrochemical instabilities connected with the electrodeposition of tin. Nevertheless spiral or target structures on the surface of the $\mathrm{Ag}-\mathrm{Sn}$ coatings were still not observed.

In the present study the electrolyte composition was the same concerning the concentrations of silver and the complex forming agent KSCN like in our previous studies [7]. Tin was introduced as pyrophosphate salt and instead of $\mathrm{Na}_{2}$ EDTA Seignette salt was used. The complex-forming agent for tin potassium pyrophosphate was introduced in twice higher amount compared to the previous investigations. A stable electrolyte was formed allowing the deposition of alloys with a tin content up to about 75 wt. \% (Figure 4).

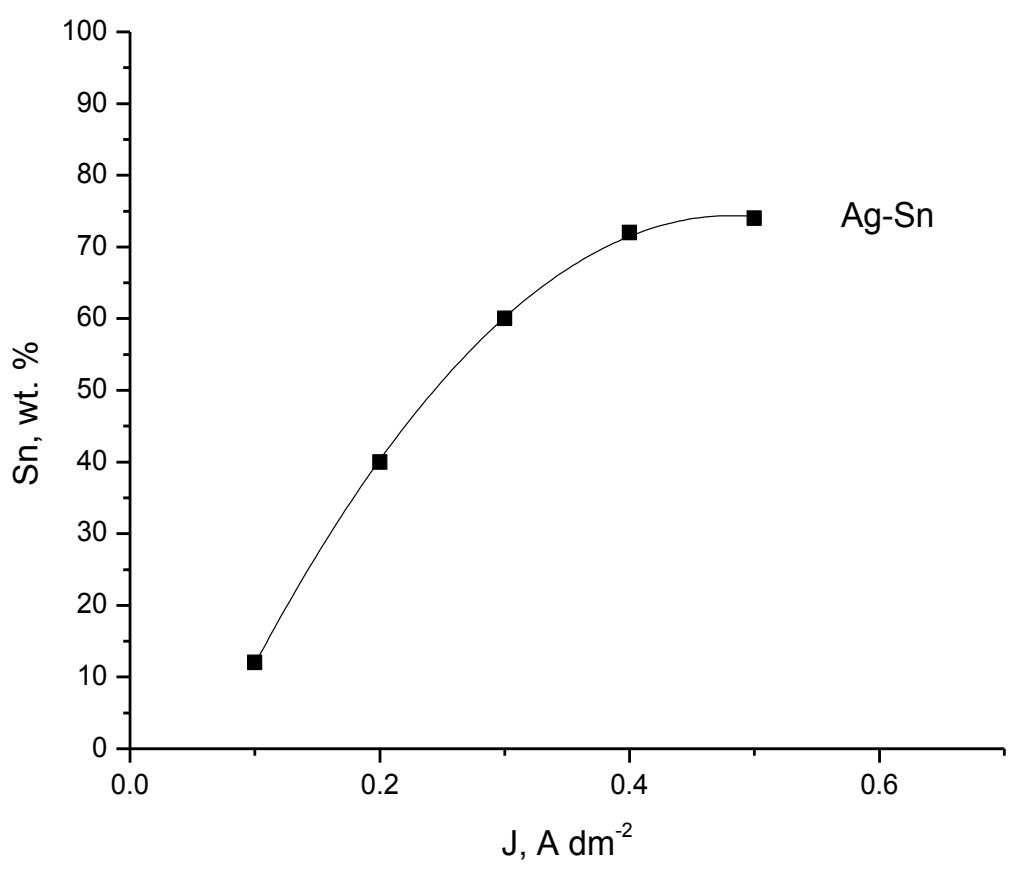

Figure 4 - Tin content of the Ag-Sn alloy deposits depending on the current density.

At low current densities the coatings are bright, silver-like. With the increasing of the current density the coatings become visibly heterogeneous. In the upper part of the electrode the coatings are richer in tin, and in the bottom - of silver. The high tin percentage results again in the deposition of heterogeneous multiphase coatings formed by different phases of the alloy. The x-ray spectra of the samples show the presence of several phases in the deposit, but similarly to the 
previous studies using other electrolyte formulation, the phases forming the coating at higher tin contents are mainly $\mathrm{Ag}_{3} \mathrm{Sn}$ and pure Sn (Figure 5).

Upon reaching up to about $42-50$ wt. \% tin ordered spatio-temporal structures on the surface of the electrode - spirals with more than 10 runs could be seen even with naked eyes (Figure 6). Similar structures were not observed during electrodeposition in cyanide-pyrophosphate electrolytes [7], as well as in any other electrolyte for deposition of the alloy. In these electrolytes the observed spatio-temporal structures are only in the form of waves.

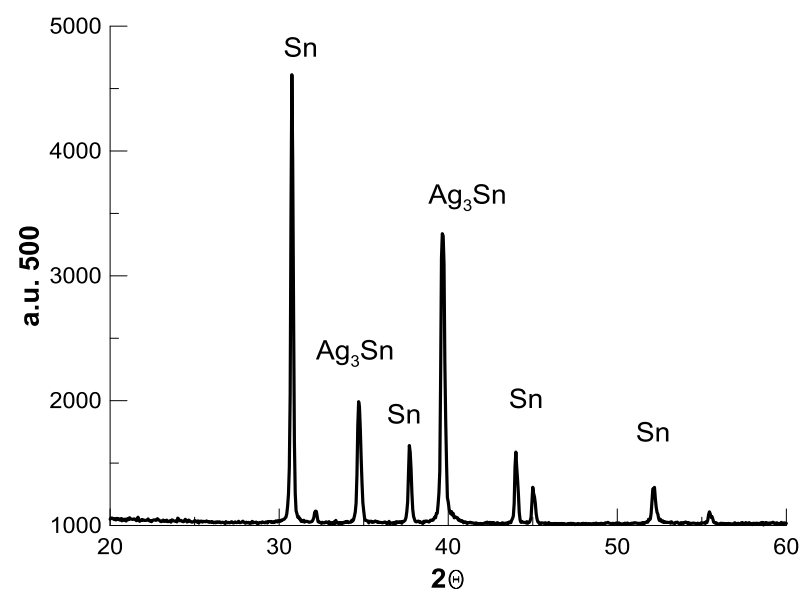

Figure 5 - X-ray diffractogram of an alloy coating; 56 wt. \% Sn $\left(0.3 \mathrm{~A} \mathrm{dm}^{-2}\right), 9 \mu \mathrm{m}$.

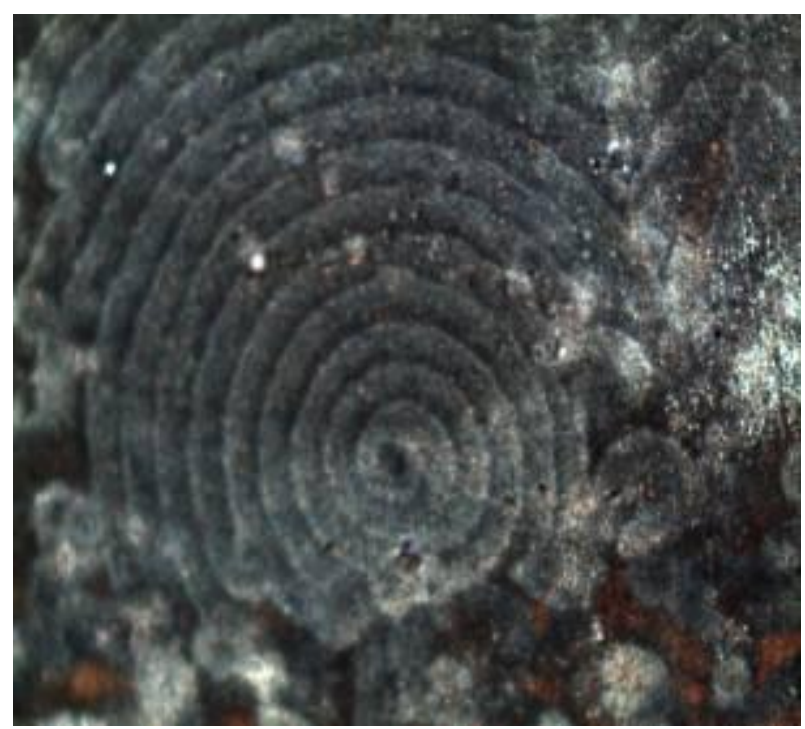

Figure 6 - Spiral pattern in electrodeposited Ag-Sn alloy coating. Width of the image $-1 \mathrm{~mm}$ $X$-ray diffractogram is shown in Figure 5.

\subsection{Electrodeposition of Pd-In alloys}

The main reason to alloy palladium with indium is two-fold: once, to decrease internal stress of electrodeposited pure palladium coatings and second, to obtain colored coatings (according to metallurgical phase diagram some $\mathrm{Pd}$-In phases are colored - from yellow, to violet) [42].

The possibility to deposit palladium-indium alloys from ammoniacal-EDTA baths under direct and pulse currents was described in detail by the group of Russian scientists [43-45]. The investigations on the internal stress of the indiumpalladium coatings, obtained from these electrolytes show, that coatings with a low content of indium (about 1.8 wt. \%) are cracked. In the alloys with indium content more than 13 wt. \% the internal stress is much lower and the coatings are not cracked. It is supposed that the decrease of the internal stress in the alloys with 20 wt. \% of indium is due to the simultaneous action of two opposite effects: A decrease of the hydrogenation of the alloy and an increase of the number of defects in the crystallites during the formation of the saturated solid solution. The phase composition of the electrodeposited palladium-indium alloy is compared with the metallurgical ones in the paper of Reshetnikova et al. [46]. It proves that the chemical compound Pdln with a homogeneity region between 45 and 70 wt. \% of indium (which is wider than the metallurgical one) has a pink-lilac colour. Interesting properties of the intermetallic compound like increased hardness and low friction coefficient are reported [47].

Electrochemical investigations on the deposition of the alloy are performed in noncyanide citrate electrolytes in our previous studies [48]. The deposition of alloy coatings with up to 20 wt. \% indium is possible from this electrolyte (Figure 7). This offers the possibility to obtain multiphase coatings with an optical heterogeneity of the surface, which at certain conditions could organize themselves in periodical spatio-temporal structures onto the electrodeposited surface of the alloy due to the presence of intermetallic compounds indicated in the phase diagram of the alloy. Recently, it was established, that during electrodeposition of other indium alloys (cobaltindium and silver-indium ones) the phenomena of self-organisation were observed $[8,49]$.

The coatings deposited in the interval of current densities between $0.1-0.3 \mathrm{~A} \mathrm{dm}^{-2}$ are palladium-like and at higher current densities they become darker and powdery. Higher contents of indium in the coatings could not be reached, i.e deposits with pink-lilac colour, which should be obtained at higher indium percentages, could not be deposited. The cathodic current efficiency was about $90 \%$.

At the average content of $11-17 \mathrm{wt} . \%$ of indium spatio-temporal structures in form of waves, targets and spirals with a period of $50-200 \mu \mathrm{m}$ were observed onto the electrode surface. Some 3D-like surface morphology formed by polycrystalline alloy 
aggregates is visible. The rough structures shown in the upper part of Figure 8 consist of finer structured patterns well expressed also in the lower part of the image in form of waves targets and

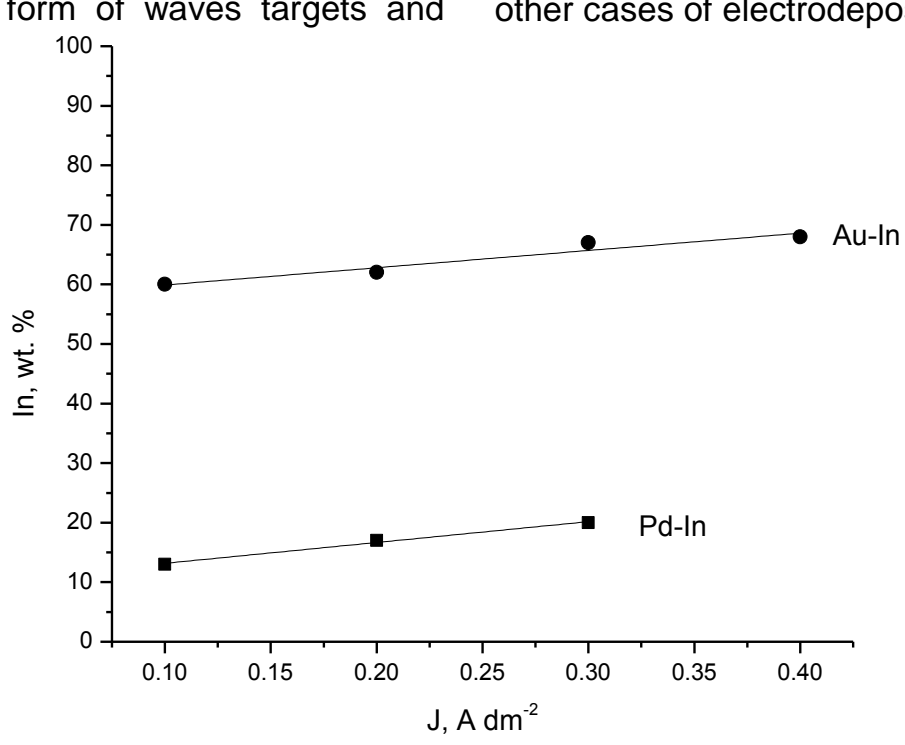

Figure 7 - Indium content in the noble metal alloys Pd-In and Au-In

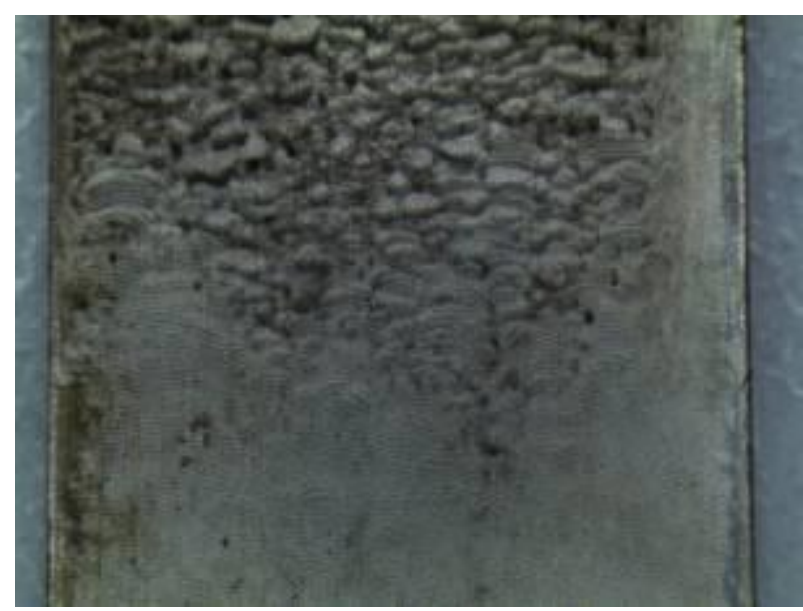

Figure 8 - Spatio-temporal structures on the surface of a Pd-In alloy coating $18 \mathrm{wt}$. \% In; 0.1 A.dm ${ }^{-2}, 1.4 \mu \mathrm{m}$. Width of the electrode $-1 \mathrm{~cm}$.

The light and dark areas of the spatio-temporal structures should consist of different phases of the alloy system, which have different optical properties. The $x$-ray investigations show, that the different zones are formed by the phases $\mathrm{Pd}$ and $P d_{0.85} I_{0.15}$ (Figure 9). In this case the determination of the phase composition of the different zones of the structures was possible without applying electrochemical methods (ALSV). spirals. The self-organisation phenomena are observed in different scales on the same electrode for the first time in this system, similar to many other cases of electrodeposited alloy coatings..

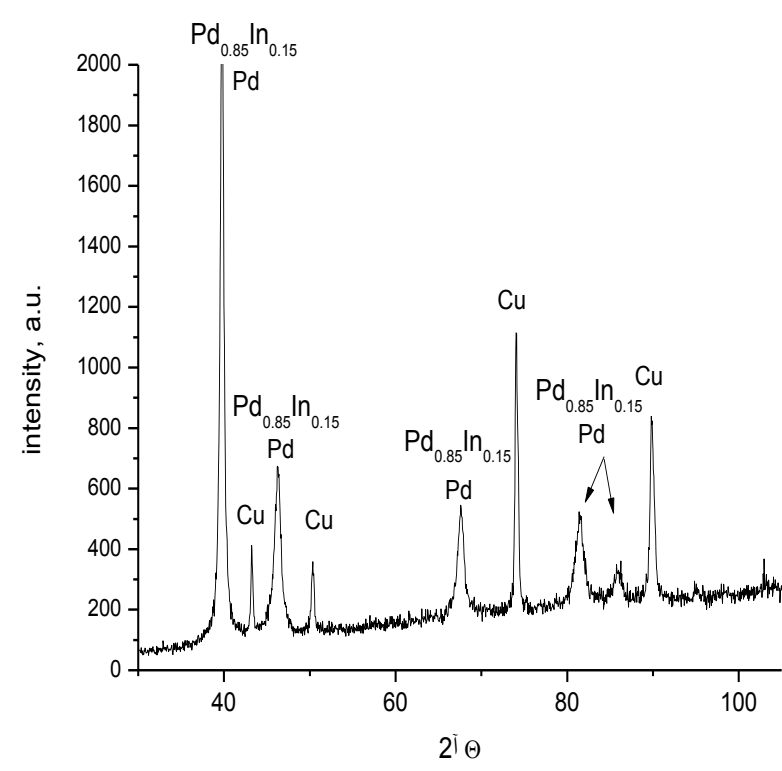

Figure 9 - X-ray diffractogram of the coating presented in Figure 8

\subsection{Electrodeposition of Au-In alloy coatings}

According to the phase diagram, the goldindium alloy system has a couple of intermetallic, differently coloured phases, in particular a blue Auln $_{2}$ and a white Auln phase which makes the alloy rather interesting for jewellers and is known as blue gold [50].

The electrodeposition of Au-In alloys is performed from different types of electrolytes alkaline with selenium and tellurium as brighteners 
[51] and acid cyanide containing baths [52]. The electrodeposition of the alloy from alkaline electrolytes is limited to some extend due to the complexity during the preparation of the alloy electrolytes: one of the most used salts of gold is cyanide, and cyanide ions lead to precipitation of indium ions. The difficulties were overcome in the silver-indium electrolytes by the development of a procedure for preparation of a clear indium cyanide electrolyte [53].

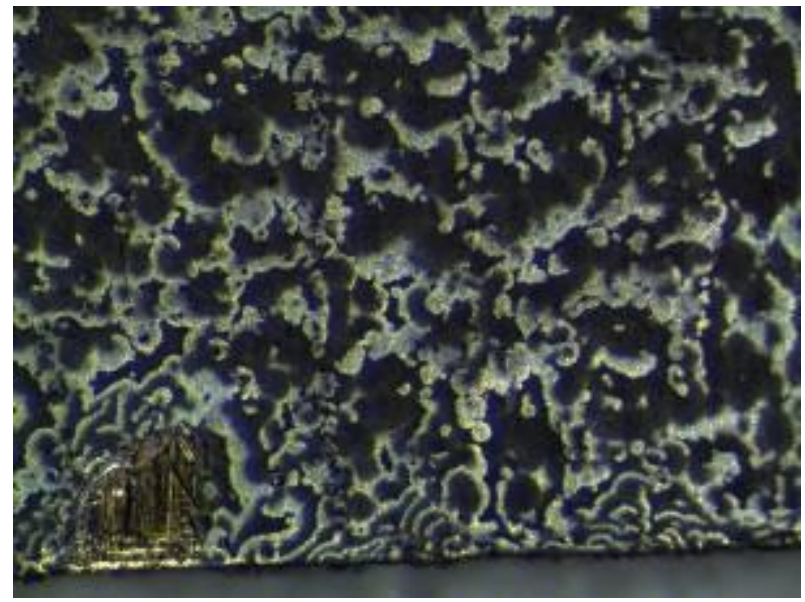

Figure 10 - Appearance of ordered structures on the surface of an Au-In coating; Width of the image - $0.5 \mathrm{~cm} ; 0.4 \mathrm{~A} \mathrm{dm}^{2} ; 74.1 \mathrm{wt}$; \% In; $1.2 \mu \mathrm{m}$.
In this work an attempt has been made to apply an acid glycine containing electrolyte for deposition of the gold-indium system (see Table 1). There is no information in the literature about the complex forming effect of glycine onto the indium or gold ions. But the glycine is a suitable complex forming agent for some metals such as $\mathrm{Ag}, \mathrm{Pd}, \mathrm{Cu}$ and other metals. From this electrolyte coatings with a stable indium content about $70-75$ wt. \% can be deposited in a wide range of current densities (0.2$0.8 \mathrm{~A} \mathrm{dm}^{-2}$ ) (Figure 7). The coatings are greyishwhite and their surface is heterogeneous (Figure 5 $a, b)$. This heterogeneity, as well the formation of ordered structures on the surface of the coating is well visible also in the microscope (Figure 10).

The optical heterogeneity is originated by the simultaneous co-deposition of different phases of the alloy system. The x-ray diffractogram of the coating in which some ordered patterns can be observed shows the presence of the cubical phase Aul $_{2}$ besides the tetragonal phase of In (pdf 98005-3091) (Figure 11). It is evident that only these phases are present in the coating and they form the dark and light zones of the observed patterns. The system is simple and additional determination of the phase composition of the structure by using electrochemical methods is not necessary.

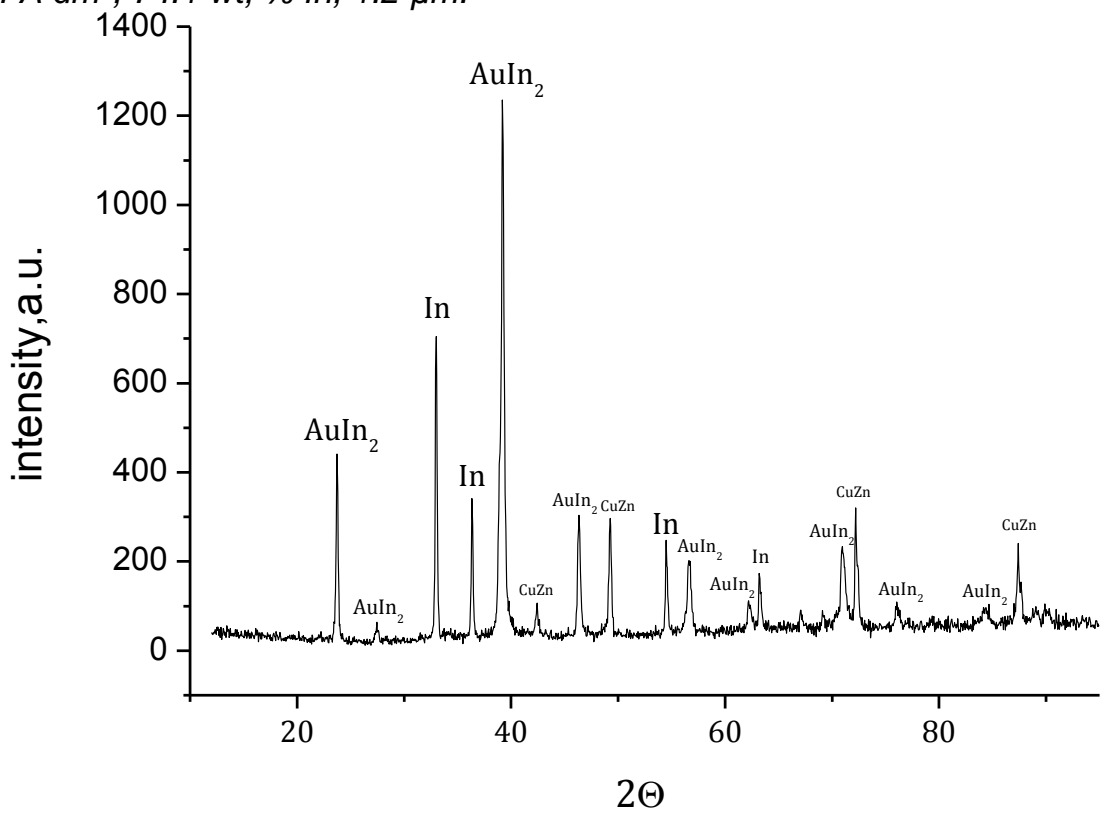

Figure 11 - X-ray diffractogram of the Au-In alloy coating shown in Figure 10.

Recently, a conclusion was made that similar structures in other alloys could be obtained when simultaneous deposition of two phases with a similar crystal lattices takes place. However, this is not the case in here - In has a tetragonal lattice and Auln ${ }_{2}$ has a cubic once, so that the similarity is not only the reason for the structure formation. The glycine electrolyte seems to be appropriate for the future investigation in order to obtain better defined spatio-temporal structures onto the cathodic surface. 


\section{Acknowledgments}

The authors express their gratitude to Bulgarian National Science Fund for the financial support of project T02-27/2014. Thanks to V. Kostov, A. Gjozova and M. Georgiev for performing parts of the experiments.

\section{REFERENCES}

[1] E.Raub, A.Schall (1938) Silber-Indium Legierungen. Ein Beitrag zur anlaufbesteaendigen Silberlegierungen, Zeitschrift fur Metallkunde, 30 , 149-151.

[2] I.Kristev, M.Nikolova (1986) Structural effects during the electrodeposition of silver-antimony alloys from ferrocyanide-thiocyanate electrolytes, J Appl Electrochem, 16, 875-878.

[3] I.Kristev, M.Nikolova, I.Nakada (1989) Spiral structures in electrodeposited silver-antimony alloys, Electrochim Acta, 34, 1219-1223.

[4] I.Krastev, T.Valkova, A.Zielonka (2004) Structure and properties of electrodeposited silver-bismuth alloys, J Appl Electrochem, 34, 79-85

[5] T.Dobrovolska, L.Veleva, I.Krastev, A.Zielonka (2005) Composition and structure of silver-indium alloy coatings electrodeposited from cyanide electrolytes, J Electrochem Soc, 152, C137-C142.

[6] T.Dobrovolska, I.Krastev, A.Zielonka (2010) Pattern formation in electrodeposited silver-cadmium alloys, ECS Transactions Current Trends in Electrodeposition, an Invited Symposium - 216th ECS Meeting, Vienna, p. 1-9.

[7] A.Hrussanova, I.Krastev (2009) Electrodeposition of silver-tin alloys from pyrophosphate-cyanide electrolytes, J Appl Electrochem, 39, 989-994.

[8] I.Krastev, T.Dobrovolska, U.Lačnjevac, S. Nineva (2012) Pattern formation during electrodeposition of indium-cobalt alloys, J Solid State Electrochem, 16 , 3449-3456.

[9] A.Hrussanova, I.Krastev, A.Zielonka (2011) Effect of the electrolyte composition on the electrodeposition of $\mathrm{Cu}-\mathrm{Sb}$ alloys from methanesulphonate-tartrate electrolytes, Zastita materiala, 52(3), 145-151.

[10] S.Nineva, Ts.Dobrovolska, I.Krastev (2011) Electrodeposition of Sb-In, Sb-Co and In-Co alloys, Zastita materiala, 52(2) 80-84.

[11] I.Krastev, M.E.Baumgaertner, C.Raub (1992) Stromoszillationen bei der galvanischen Abscheidung. Untersuchungen der Silber-AntimonLegierungsabscheidung. Teil 2., Metalloberflache, 46(3), 115-119.

[12] T.Dobrovolska, D.A.Lopez-Sauri, L.Veleva, I.Krastev (2012) Oscillations and spatio-temporal structures during electrodeposition of $\mathrm{AgCd}$ alloys, Electrochim Acta 79, 162-169.

[13] A.Hrussanova, I.Krastev, G.Beck, A.Zielonka (2010) Properties of silver-tin alloys obtained from pyrophosphate-cyanide electrolytes containing EDTA salts, J Appl Electrochem, 40, 2145-2151.

[14] I.Krastev, M.Baumgaertner, Ch.J.Raub (1992) Stromoszillationen bei der galvanischen Abscheidung. Untersuchungen der Silber-Antimon-
Legierungsabscheidung. Teil 1., Metalloberflache, 42(2), 63-68.

[15] A.Brenner (1963) Electrodeposition of Alloys. Principles and Practice, Academic Press, New York, p. 615.

[16] I.Kristev, M.Nikolova (1986) Phase composition and structure of silver-antimony alloy deposits plated from ferrocyanide-thiocyanate electrolytes, J Appl Electrochem, 16, 867-874.

[17] I.Krastev, T.Dobrovolska (2013) Pattern formation during electrodeposition of alloys, J Solid State Electrochem, 17, 481-488.

[18] T.Dobrovolska, I.Krastev, B.M.Jović, V.D.Jović, G.Beck, U.Lačnjevac, A.Zielonka (2011) Phase identification in electrodeposited $\mathrm{Ag}-\mathrm{Cd}$ alloys by anodic linear sweep voltammetry and X-ray diffraction techniques, Electrochim Acta, 56, 43444350.

[19] S.Nakabayashi, I.Krastev, R.Aogaki, K.Inokuma (1998) Electrochemical instability of $\mathrm{Ag} / \mathrm{Sb} \mathrm{co}$ deposition coupled with a magnetohydrodynamic flow, Chem Phys, Lett 294, 204-208.

[20] T.Dobrovolska, R.Kowalik, P.Zabinski, I.Krastev (2008) Investigations of the surface morphology of electrodeposited $\mathrm{Ag}$-In coatings by means of optical, scanning-electron and atomic-force microscopy, Bulg Chem Commun, 40, 254-260.

[21] T.S.Dobrovolska, I.Krastev, P.Zabinski, R.Kowalik, A.Zielonka (2011) Oscillations and self-organization phenomena during electrodeposition of silverindium alloys. Experimental study, Arch Metall Mater, 56, 645-657.

[22] I.Krastev, M.T.M.Koper (1995) Pattern formation during the electrodeposition of a silver-antimony alloy, Phys A Stat Mech Appl, 213, 199-208.

[23] S.Nakabayashi, K.Inokuma, A.Nakao, I.Krastev (2000) Colliding spiral waves propagating on the electrode, Chem Lett, 29(2), 88-89.

[24] T.Dobrovolska, G.Beck, I.Krastev, A.Zielonka (2008) Phase composition of electrodeposited silver-indium alloys, J Solid State Electrochem, 12, 1461-1467

[25] T.Dobrovolska, V.D.Jović, B.M.Jović, I.Krastev, (2007) Phase identification in electrodeposited AgIn alloys by ALSV technique, J Electroanal Chem, $611,232-240$.

[26] I.Krastev, N.Petkova, A.Zielonka (2002) Properties of silver-antimony alloys electrodeposited from ferrocyanide-thiocyanate electrolytes, J Appl Electrochem, 32, 811-818.

[27] I.Krastev, T.Dobrovolska, R.Kowalik, P.Zabinski, A.Zielonka (2009) Properties of silver-indium alloys electrodeposited from cyanide electrolytes, Electrochim Acta, 54, 2515-2521.

[28] H.R.Khan, O.Loebich, I.Krastev, C.Raub (1994) Investigation of the structure, texture and temperature dependent electrical resistivity of $\mathrm{Ag}$ Sb electrodeposits, Trans Inst Met Finish, 72, 134138.

[29] S.Nineva, T.Dobrovolska, I.Krastev (2011) Properties of electrodeposited silver-cobalt coatings, J Appl Electrochem, 41, 1397-1406. 
[30] I.Golvano-Escobal, B.Ozkale, S.Surinach, M.D. Baro, T.Dobrovolska, I.Krastev, S. Pane, J.Sort, E.Pellicer (2014) Self-organized spatio-temporal micropatterning in ferromagnetic Co-In films, J Mater Chem C 2, 8259-8269.

[31] I.Krastev, A.Zielonka (2002) Electrodeposition and properties of cyclically modulated silver-antimony alloys, J Appl Electrochem, 32, 1141-1149.

[32] I.Krastev, T.Valkova, A.Zielonka (2005) Electrodeposition and properties of cyclicallymodulated silver-bismuth alloy coatings, Galvanotechni, 96, 1790-1795.

[33] Y.N.Sadana, J.P.Singh, R.Kumar (1985) Electrodeposition of antimony and antimony alloys, A review, 24, 319-353.

[34] R.S.Saifullin, P.S.Melnikov, G.S.Vozdvizhenskii (1971) USSR patent [306193].

[35] V.S.Galinker, A.I.Yaroshinskii, O.K.Kudra (1974) Study of a copper-antimony pyrophosphate electrolyte containing the solid phase $\mathrm{Sb}_{2} \mathrm{O}_{3}$ Protection of Metals, 10, 423-424.

[36] E.Raub (1952) Der Aufbau der galvanischen Legierungsniederschlage. Teil VII..Die KupferWismut und die Kupfer-Antimon-Legierungen, Zeitschrift fuer Erzbergbau Metallhuettenwesen, 5, 153-160.

[37] E.Raub, G.Dehoust, K.Ramcke (1968) Die galvanische Abscheidung von Legierungen des Antimons mit Kupfer, Silber und Gold. Metall, 22(6), 573-576.

[38] P.S.Melnikov, R.S.Saifullin (1972) Electrodeposition of bright and abrasion resistant $\mathrm{Cu}-\mathrm{Sb}$ alloy coatings from a self-regulating electrolyte, Protection of Metals, 8, 355-358.

[39] T.Z.Akhmetov, B.K.Toibaev, A.I.Zebreva (1973) O цементации меди и сурьмъ амальгамой цинка, Elektrokhimija, 9(9), 1306-1309.

[40] L.V.Yurinskaia, S.Ya.Popov (1968) Protective Metallic and Oxide Coatings, Metal Corosion and Electrochemistry, Nauka, Moskva-Leningrad.

[41] O.K.Kudra, V.S.Galinker, A.I.Yaroshinskii (1975) Pyrophosphate electrolyte for electrodepositing copper-antimony alloys, Zhurnal khimii Abstract 18L343; Chem. Abstracts , 83, 67731w, 1974.

[42] E.M.Savitskij (1984) Blagorodnye metally, Metallurgia, Moscow.

[43] S.N.Vinogradov, Y.Perelygin (1980) Electrodeposition of palladium-indium alloy, Protection of Metals, 16[4], 409-410.

[44] S.N.Vinogradov, Y.Perelygin, E.Efimov (1985) Electrodeposition of palladium-indium alloy from ammoniacal-citrate electrolyte, Protection of Metals, 21(1), 126-128.

[45] S.N.Vinogradov, Y.Perelygin, E.Efimov (1987) Kinetic investigations of indium-palladium alloy electrodeposition, Elektrokhimija, 23(7), 909-911.

[46] N.F.Reshetnikova, K.S.Pedan (1982) Electrodeposition of palladium-indium alloys, Zhurnal prikladnoj khimii, 2, 1996-1999.

[47] K.S.Pedan, N.F.Reshetnikova (1982) Electrolyte for depositing palladium-indium alloy coatings, SU931812, USSR.

[48] Ts.Dobrovolska, M.Georgiev, I.Krastev (2015) Selforganisation phenomena during electrodeposition of palladium-indium alloys, Trans Inst Met Finish, 93(6), 326-331.

[49] T.Dobrovolska, I.Krastev (2010) Electrodeposition of silver-indium alloys in Electrolysis: Theory, Types and Applications, Nova Science Publishers, Inc., p. 303-326.

[50] U.E.Klotz (2010) Metallurgy and processing of coloured gold intermetallics- Part. 1: Properties and surface processing, Gold bulletin, 43(1), 4-10.

[51] W.Kuhn, W.Zilske (1986) Bath and process for the electrolytic deposition of gold-indium alloys, USA [US4617096].

[52] L.C.Archibald, G.Sanderson (1978) Electrodeposition of white gold-indium alloy from an acid cyanide electrolyte, Trans Inst Met Finish, 55(4), 149-154.

[53] T.Dobrovolska, I.Krastev, A.Zielonka (2005) Effect of the electrolyte composition on In and Ag-In alloy electrodeposition from cyanide electrolytes, J Appl Electrochem, 35, 1245-1251.

\title{
IZVOD
}

\section{NOVI PRIMERI ELEKTROHEMIJSKI ISTALOŽENIH SISTEMA SA FORMIRANJEM ŠARA (UREĐENIH STRUKTURA)}

U ovom radu je dat pregled svih sistema elektrohemijski istaloženih legura kod kojih dolazi do formiranja šara (samo-organizovanih uređenih struktura). Mogućnost formiranja ovih struktura usled spontanog ko-taloženja različitih faza i njihovog samo-organizovanja u uređene strukture demonstrirano je za neke nove sisteme, kao što su legure Cu-Sb, Ag-Sn, Pb-In i Au-In.

Ključne reči: Elektrohemijsko taloženje legura, formiranje uređenih struktura, SEM, XRD, ALSV.

\author{
Naučni rad \\ Rad primljen: 28. 11. 2015. \\ Rad prihvaćen: 21. 01. 2016. \\ Rad je dostupan na sajtu: www.idk.org.rs/casopis
}

